\title{
Modals as Carriers of Ideology in Salmon Fishing in the Yemen
}

\author{
Gibreel Sadeq Alaghbary ${ }^{1 \& 2} \&$ Ohood Ali Al-Nakeeb ${ }^{3}$ \\ ${ }^{1}$ Taiz University, Yemen \\ ${ }^{2}$ Qassim University, KSA \\ ${ }^{3}$ Department of Linguistics, University of Kerala, India \\ Correspondence: Gibreel Sadeq Alaghbary, Center for Languages and Translation, Taiz University, Yemen; \\ Qassim University, Qassim, KSA. E-mail: gibreelsadeq@yahoo.com
}

Received: March 8, $2017 \quad$ Accepted: March 28, $2017 \quad$ Online Published: May 30, 2017
doi:10.5539/ells.v7n2p31
URL: http://doi.org/10.5539/ells.v7n2p31

\begin{abstract}
Modality encodes speakers or writers' attitudes towards, and evaluations of, people and states of affairs. These evaluative attitudes are often ideologically motivated. This paper investigates ideology as carried by modal expressions in Salmon Fishing in the Yemen. Of the ten genres constituting the narrative, the newspaper articles have been selected for analysis. The paper adopts Simpson's (1993) analytical framework, aka Critical Linguistics, in order to achieve three objectives. It aims to identify the modal expressions employed in the selected newspaper articles, classify the relevant modalized, and modally unmarked, statements, and explore the ideological assumptions and evaluations generated by the modal expressions, or their absence, in relation to the characters' attitudes towards each other and towards the thematic developments in the novel. Analysis uncovers a dichotomy constructed between the East and West. The East, represented by the salmon project, Sheikh Muhammad and the Yemeni government, is projected as submissive and inferior.
\end{abstract}

Keywords: modality, ideology, Salmon Fishing in the Yemen, critical linguistics, modality, point of view

\section{Introduction}

\subsection{Modality}

Modality is generally defined as the mode in which a proposition is framed, i.e., whether it is presented as obligatory, permissible, or advisable. Wales (2002) defines it as the "speakers' attitudes and stance towards the propositions they express" (p. 255), and it covers "all those features of discourse which concern a speaker's or writer's attitude to, or commitment to, the value or applicability of the propositional content of an utterance, and concomitantly, his relationship with whoever he directs the speech act to" (Fowler, 1977, p. 3). In linguistic parlance, modality is "a general term which describes unrealized states and possible conditions and the forms of language which encode them such as 'possibly', 'perhaps', 'could be', 'ought to be'" (Carter et al., 1997, p. 224).

Modality is classified on the basis of the attitude encoded by the speaker's modal expressions into four modal systems: "the deontic, along with the closely related boulomaic system; the epistemic system with its subsystem of perception modality" ([original emphasis], Simpson, 1993, p. 43). These modalities convey the speaker's evaluation of the necessity, desirability and possibility of the proposition. In particular, necessity, obligation, requirement and desirability are realized in the two related systems of deontic and boulomaic modality, whereas possibility, cognition and perception are expressed by epistemic modality and its subsystem of perception modality. Deontic modality is "directive" because "the event is controlled by circumstances external to the subject of the sentence (more strictly the person or persons identified by the subject)" (Palmer, 2003, p. 7), whereas epistemic modality "is concerned solely with the speaker's attitude to status of the proposition" (p. 7). Such stances, expressed either via deontic or epistemic modalities, are articulated either internally through the speaker's own consciousness or his/ her evaluation of other people, or externally through the point of view of an outsider (Simpson, 1993).

The ideological outlooks and positionings carried by modality markers are often expressions of the deep-seated opinions of a group or individuals. In other words, they are motivated by certain beliefs and attitudes, known as ideologies, which are cultivations of social, religious, political and cultural considerations. 


\subsection{Ideology}

The term 'ideology' has, since the 18th century, attracted the attention of scholars from such disciplines as philosophy, literary theory, sociology, psychology, linguistics and discourse analysis. The philosopher de Tracy (1796) offered one of the earliest conceptualizations of the term. He calls it the "science of ideas" (cited in Eagleton, 1991, p. 66). In the field of Marxist studies, Althusser (2003) defines it as the "representation of the imaginary relationship of individuals to their real conditions of existence" (cited in Sadati, 2013, p. 481). In sociology, ideology is "the ideas of the ruling class", which are the "ruling intellectual force" (Marx \& Engels, 1970, p. 64). More relevantly, in discourse studies van Dijk's (1998) relates ideology directly to society, cognition and discourse. He argues that "ideologies consist of socially shared beliefs that are associated with the characteristic properties of a group, such as their identity, their position in society, their interests and aims, their relations to other groups, their reproduction, and their natural environment" (p. 12). The diversity of these accounts of 'ideology' is explained by the differences in perspective from which the term is viewed. More relevant to the thematic concerns of this paper is Simpson's definition in the context of language. According to Simpson (2004), ideology is "the matrix of beliefs we use to comprehend the world and to the value systems through and by which we interact in a society" (p. 78).

Simpson's (1993) approach to ideology constitutes a major component of his approach to the investigation of the ideology in language, and, more specifically, in literature. The approach, known as Critical Linguistics, was introduced by Fowler \& Kress (1979) to critically investigate the ideological dimensions of the linguistic constituents of (literary) texts. Critical linguists such as Fowler (1991) and Simpson (1993, 2004) view ideology as a set of beliefs reflected and constructed through language. In Simpson's words, language "must, (...) reflect, and some would argue, construct ideology" ([original emphasis], 1993, p. 5). The job of a critical linguist, therefore, is to explore the text for the writer's or speaker's representation, or construction, of people, events, actions, or even ideas, and the effect of this representation, or construction, on the readers' ideological outlook.

\subsection{Salmon Fishing in the Yemen}

Salmon Fishing in the Yemen is an epistolary novel written in 2007 by Paul Torday, a British novelist. In the novel, Dr Jones, Ms. Harriet Chetwode Talbot and Sheikh Muhammed try to accomplish the project of introducing salmon fish and the sport of salmon fishing to rivers that exist among the mountains of Heraz in Yemen. This project is initially the idea of the wealthy Sheikh Muhammed who asks for Ms. Harriet and Dr Jones' assistance to achieve his dream, regardless of the cost or difficulty. After a series of complexities in the novel (i.e. the fluctuating attitude of the British governmental offices towards the project, and the trial of assassinating Sheikh Muhammed), the project commences and the Scottish fish start to swim in the Yemeni rivers. However, this action does not last for long because a huge flood suddenly happens, causing the death of the Prime Minister and Sheikh Muhammed.

\subsection{Objectives}

This study aims to

1) identify the modalized, and the modally unqualified, structures in some extracts of the novel (the selected newspaper articles),

2) classify the modalized statements along the lines of Simpson's (1993) theoretical framework, and

3) explore the ideological evaluation, encoded in the modal expression, by the characters of each other and of the events that constitute the narrative.

\section{Review of Literature}

\subsection{Analytical Framework}

\subsubsection{Simpson's Model}

Simpson's (1993) approach is mainly used in the analysis of literary texts, and this is the main reason for selecting it as the analytical framework in this study. The approach investigates point of view using modality as the analytical tool. Modality, argues Simpson, "can count systematically for the different points of view exhibited by many works of narrative fiction" [original emphasis] (p. 8).

Simpson (1993) explains the different functions of modality in terms of four systems: the deontic, boulomaic, epistemic, and perception systems. Deontic modality connotes the speaker's desire for, requirement of, and commitment to the realization of the proposition expressed by the statement. It is typically carried by modal auxiliaries of permission, requirement and obligation. Other markers include modal lexical verbs such as require, and the adjectival/ participial construction (be+ adjective/ participle + to/that). Boulmaic modality is 
"extensively grammaticized in English in expressions of desire" (Simpson, 1993, p. 48). Linguistic carriers of boulmaic modality include modal lexical verbs like hope, regret and wish, modal adverbs expressing desire (e.g., hopefully), and the adjectival/ participial construction (be+ adjective (i.e., regrettable)/ participle (desire + to/that). Both systems are interrelated because they concern the speaker's communication of duty, obligation, commitment and desirability.

Similarly, the epistemic and perception systems are connected. Although perception modality is considered as a subsystem of epistemic modality (Simpson, 1993), they both reflect the speaker's confidence or lack of confidence towards the truth of a proposition. Epistemic modality is carried by modal expressions denoting knowledge, cognition and belief, and perception modality is realized by verbs, adjectives or adverbs of human perception. Epistemic modality can be triggered through modal auxiliaries (e.g., could be; might have+ participle), modal lexical verbs (e.g., assume), modal adverbs such as certainly, adjectival constructions (be+ adjective+ to/that) and conditional structures. Perception modality is carried by modal lexical verbs such as seem to be, modal adverbs clearly, evidently, adjectives clear, and comparative structure of perception i.e., look as if (Lyons, 1977; Simpson, 1993).

Simpson (1993) outlines this model in the context of point of view in fiction. Based on the position from which a story is narrated, Simpson speaks of category A and category B and uses modality to generate nine different modes out of the two categories. These nine modes are distinguished by the shading of a text, which is the foregrounded system of modality employed and the kinds of modal expressions used (McIntyre, 2006). He mentions three different shadings, positive, negative and neutral. In positive shading, the deontic and boulomaic systems of modality are used. Negative shading, however, includes modal expressions that belong to epistemic and perception modalities. The third shading (neutral) is marked by 'categorical assertions' (Simpson, 1993).

In Simpson's (1993) 'category A', the narrator is one of the participating characters in the story and it is realized in the use of the pronoun 'I' or 'we'. This category is divided further to category A positive, negative or neutral. Category A positive "is more co-operatively oriented towards the reader" (p. 52) and it foregrounds the "narrator's desires, duties, obligations and opinions vis-à-vis events and other characters" (p. 51), so that s/he becomes the source of power in the text. On the other hand, in category A negative the narrator tends to show reluctance towards expressing feelings or opinions, and is positioned as unassertive regarding interpreting propositions. No subjective evaluation is attempted in neutral shading, nor are there any descriptions of feelings or opinions. Sentences tend to be short and unconnected (Simpson, 1993).

In 'category B' narration, the story is told from a third-person perspective, presented either as in the form of a narrator, who narrates the story from a position that is outside the consciousness of any of the characters, and is known as category B in narratorial mode, or as a 'reflector'. The latter is a third-person narrator who moves into the consciousness of one of the characters. This mode of narration is called category $B$ in reflector mode.

\subsection{Previous Studies}

\subsubsection{Studies on Modality}

Modality, as a tool for the investigation of ideological control, has been applied to different text types (Alaghbary, 2014; Bonyadi, 2011; Kačmárová, 2011). It has been used in the analysis of such texts as university prospectuses, newspaper articles, editorials, political speeches, and Internet chats.

Alaghbary (2014) studies six statements by Obama (dated between January 14 and April 8, 2011) on the 2011 Arab uprisings using the critical stylistic model proposed by Jeffries (2010). The objective is "to examine how Obama's speeches on the Arab Spring articulate US ideological assumptions about the pro-reform protests (and protestors), the aggressive responses of the embattled regimes and the conflict which developed as a result" (Alaghbary, 2014, p. 151). Analysis of modality in the statements reveals that modal expressions "are deployed to communicate position on conflict and ideological evaluation of parties in conflict" (p. 172).

Bonyadi (2011) analyzes media discourse, specifically newspaper editorials in the New York Times and in Tehran Times. The study compares the two papers in terms of the use of modals and concludes that the predictive modal will in New York Times is highly used which indicates the paper's concern with "what would happen in the future" (p. 1). The use of modals of necessity in Tehran Times, on the other hand, shows that editorial writers are "occupied with what should be done" (p. 1). Analysis of the editorials also demonstrates that they are "inclined to thematize modality" through the use of generic sentences "possibly to increase its persuasive effect" (p. 11).

Kačmárová (2011) offers a quantitative analysis on the communicative situations in the internet chatting discourse. The study samples transcripts of online chat sessions that runs into 297606 words. The target modal expressions include modal adverbials and evaluative introductory words. Results of the analysis indicate that 
modal expressions function as emphasizers to express certainty or confidence towards the truth of the propositions expressed. They are also used "to modify the effect of the verbal production of a speaker and to communicate their stance" (p. 45).

Other studies have examined the use of modality as a tool of embedding ideologies in literary texts (e.g., León, 2001; Parina \& De Leon, 2014). León (2001) employs Simpson's (1993) and Fairclough's (1994) approaches in examining the modal expressions used by the two main characters in the play The Dumb Waiter. The objective is to identify their attitudes towards each other and towards the events in the play. Conclusions of the study demonstrate that modality, realized in deontic modality, is employed to represent certain attitudes as signs of control, authority and superiority. However, epistemic modal expressions represent weakness and uncertainty. The study also shows that the change in (non)use of systems of modality results in a change of attitudes and ideological positionings.

Parina \& De Leon (2014) examine the short story Things You Don't Know by Ian Rosales in order to identify "the commonly used type of modal and modality element identified", the "speaker's attitude toward the situation or event?", and the "shade of the story based on the identified type of modality used?" (p. 93). Results of the analysis suggest that "epistemic modality is widely used" in order to "make the readers feel the uncertainty of the narrator to the attitude of the characters and to the situation or events by relying only to the external appearance or surrounding" (p. 99). The shade of the story is "negative, due to the frequent use of epistemic modality" which portrays the main character as "in a state of ambiguity" and "hesitant whenever a decision has to be made" (p. 99).

\subsubsection{Studies on Salmon Fishing in the Yemen}

There have been a few critical reviews on the novel published in British newspapers: the Age, the Guardian, the Telegraph (e.g., Collin, 2012; Jordon, 2007; Lea, 2007; Mackintosh-Smith, 2007). Some essays and articles (Al-Olaqi, 2012; Seng, 2013) have also offered reviews on the novel. In Al-Olaqi's (2012) article, literary texts including Salmon Fishing in the Yemen, that depict the images of Arabs are examined. Al-Olaqi argues that after the events of 9/11 in America "Islamist Arabs are represented as a threat to the West" in literary texts (p. 1767). Specifically, the theme of Islamic or Arabian terrorism appears in Salmon Fishing in the Yemen. Although Al-Olaqi's argument might (not) be correct, it is based on his subjective outlook of the novel. Indeed, he does not provide any linguistic evidence from the novel in support of this argument.

Seng's (2013) film review essay offers interesting arguments: first, "Yemen can be said to be constructed as the Other in the British/ Western geographical imagination of Yemen and the Middle East". He adds "the movie actively depicts Yemen as different from Britain: hot, dry and sandy" (p. 4). Second, the concept of orientalism is traced in the movie via the use of "Arabic stereotype" (p. 6). Third, the "British sensibility meanwhile is subtly constructed in contrast with the ludicrous project in Yemen and its (un-) believability" (p. 8). Lastly, "the absence of certain non-British elements indicates the producers' subjective perceptions". That is, as Stables (2012) argues, Britain is 'excellently' captured as presented through the accent and the polite address titles of the British protagonists as "Dr Jones" and "Ms Chetwode-Talbot" (cited in Seng, 2013, p. 8). On the other hand, "other governments (American or Yemeni) do not exist" (p. 8).

Al-Nakeeb (2014) applies the critical linguistic approach used in this paper to the investigation of the text, Salmon Fishing in the Yemen. The sample is the twenty-one emails of the novel, and the study concludes that the foregrounded modal system is the deontic modality which communicates the characters' assertive stances that are motivated by a number of ideologies such as "money is power... the British society is patriarchal, the British are snobbish, and Al-Qaeda is an ideologically extremist organization" (p. 10).

The few studies mentioned above necessitate a futher exploration of the novel. Thus, the present study is an extension of the literature on Salmon Fishing in the Yemen on one hand, and the interplay of modality and ideology, on the other.

\section{Methodology}

\subsection{Data}

Salmon Fishing in the Yemen is a modern epistolary novel written in ten different genres, viz., letters, memos, emails, newspaper articles, autobiographies, testimonies, scientific proposals, interviews, TV scripts and discussions. Of these discourse types, the study selects, for the purpose of analysis, the newspaper articles.

The choice of this genre over others is motivated by a number of reasons. First, newspaper articles claim, at least some measure of, objectivity, and it will be interesting to examine this claim, in the novel, against the possible existence of ideologically slanted representation. Second, the articles in the novel appear in eastern and western 
newspapers, which offers different perspectives on the social, political, economic, and religious events in the narrative.

The total number of articles in the novel is nine, which are grouped in two sets according to the stage at which they occur in the narration (see Appendix A and B). The first set appears in the middle of the novel, after the salmon project is publically known. It includes five articles - the first is published in the Yemeni newspaper, the Yemen Observer, while the other four appear in different English papers including the International Herald Tribune, and the Times. These articles present attitudes towards the project, Sheikh Muhammed (as representatives of the east in the novel) and Ms Harriet, the British government and governmental fisheries offices. The other set, which includes four articles, appears after the termination of Dr Jones' employment contract and offers comments on the assassination attempt of Sheikh Muhammed and on the British governmental offices' change of interest in the project.

\subsection{Procedure}

The nine articles will be subjected to a Critical Linguistic analysis along the lines proposed in Simpson (1993). Analysis of each article goes through three stages that relate to the three objectives of the paper. First, the markers of modality in each statement are identified. All modal auxiliaries, modal adverbials, verbs, nouns, adjectives and phrases expressing modality will be highlighted. The second paragraph will categorize the identified expressions as deontic, boulomaic, epistemic or perception modality markers. The mode of narration is also identified and classified on the basis of the shading angle from which the events are narrated-positive, negative or neutral shading. This is how characters' ideologies are reported, interpreted or manipulated. The third stage of the analysis explores the characters' ideological evaluation, encoded in the markers of modality, of each other and of the unfolding narrative.

\section{Results}

\subsection{First Set of Articles}

\subsubsection{Article Number 1}

The first article features a number of evaluative lexical units such as adverbs understandably; nouns legitimacy, desert; adjectives scientific, lively, leading, real; clauses neither a realistic nor an economic. There is the passive is entitled and passive progressive is being debated, is being supported, being boosted. Should, a boulomaic modal verb predicated upon the subject we, is also employed.

These deontic and boulomaic markers classify the article as positively shaded. However, there is a shift in the position of the narrator. In the first and last paragraphs, the viewing position is internal; the agent is we in reference to the Yemen Observer, which sets the article within category A narration. However, in the middle of the article, externality is projected with the use of parallel passive structures, classifying it under category B narration. This shift of point of view from category A to B is significant because it results in a "re-orientations of POV" (Simpson, 1993, p. 74).

The positive evaluative structures in the article and the use of internal viewing position reveal the newspaper's assertive attitudes towards the salmon project. The Yemenis, on the other hand, are less passionate about it. This evaluation is structured in passive sentences is being debated that undermine the negative prosody and foregrounds the positive construction.

\subsubsection{Article Number 2}

Here, there is perception modality realized by the modal lexical verb of perception speculate, the verb of perception appears to be (repeated twice), the adverb of perception likely and the adjectival construction it is likely that, the negative epistemic modal verbs could not, may not, will not be. And some structures, associated with politics and the project, are foregrounded via repetition: the nouns government (repeated five times), the prime minister, officials (repeated twice), and the adjective political (repeated twice).

Epistemic and perception modalities classify the article as category B in the narratorial mode negative. The narrator is situated outside the consciousness of the characters, which reflects an external point of view. This externality, coupled with the negative shading, underlines the newspaper's detachment from the content of the propositions and attempt to evade commitment to the truth of the propositions.

Negative modality markers foreground the newspaper's unassertive attitude towards the truth of the propositions about the US and the British policies, and the project. This attitude is motivated by contradictory positions of the British government, which supports the project while it "currently involves further military build-ups in Saudi Arabia and Iraq" (Torday, 2007, p. 88). Given this background, the British government's inconsistent attitude is 
"likely an effort to soften the impact of recent military actions in southern Iraq" (p. 88).

\subsubsection{Article Number 3}

This article is written in categorical assertions. Most of the propositions are also structured in passive structures such as concerns were raised and there are some evaluative adjectives and adverbs.

It is written in category B in narratorial mode neutral. The newspaper is positioned outside the story and point of view is established through a "bird's-eye" view, so that there is no direct description of the thoughts and feelings of the characters. Such neutrality is a characteristic feature of newspaper articles and detective stories (Simpson, 1993).

The unmodalized language and passivization reveal an objective commentary on Sheikh Muhammed, the project and the governmental offices. And the use of categorical assertions constructs the Times as a neutral newspaper. This construction of the Times is itself ideological; it indicates the novelist's ideological slant in favor of the newspaper and attempt to impose this evaluation on his readers.

\subsubsection{Article Number 4}

Here, there is an extensive use of evaluative expressions such as verbs (have sung the praises), noun phrases ( $a$ reputation for), adjectives pre-modified by evaluating adverbs (the most boring of sports), adverbs modifying nouns (absolutely no benefit), a clause post-modifying a noun "the idea that the mountains of the Heraz... are soon to become the next playground for internationally minded game fishermen" (Torday, 2007, p. 90). References to money are personified (money talks and the millions of pounds that Sheikh Muhammad... is spending are talking loudly enough).

This article belongs to category A narration because of the repetition of the agent we (six times) and the possessive adjective our (four times), which results in an internal point of view. The Trout and Salmon is presented as one of the characters in the story and projected as being completely knowledgeable of the feelings and thoughts of the other characters. The article is long and contains complex sentences. The second paragraph includes a sentence running into 54 words. There is also a shift in shading from positive to negative in paragraph 4 realized in 'would not have anticipated' and 'would become involved'. In this sentence, there is a negative epistemic modal verb phrase consisting of seven verbs that is used in reference to the British organization responsible for accomplishing the project. It indicates the disappointment by the British government which is sarcastically constructed in the same paragraph as bought by a Yemeni sheikh.

Evaluative structures create a positive shading, which highlights the newspaper's assertive attitude towards the west and a sense of superiority to the east. The west is presented as the owner of the sports fly fishing and salmon fishing; they have the latest in clothing technology and they are making films and television programmes about fishing. The article constructs the west as more trendy and superior to the east. This ideological evaluation is carried forward with the negative prosody associated with the project, which is constructed as absurd, useless, adventurous.

\subsubsection{Article Number 5}

The fifth article is the shortest; it is a 109-word paragraph. Some evaluative adjectives and verbs are used. Verbs entailing deontic modality are also employed (refused to), repeated twice, and would like to, which denotes boulomaic modality.

Using the agent, we (four times) and possessive adjective our (twice) categorizes the article within category A narration. The Sun is a participating character in the novel; it is constructed as a source of authority and power. This is manipulative of the ideological attitude of the newspaper readers.

Deontic and boulomaic modalities indicate assertive attitudes towards the project, Yemen and Ms Harriet. The project is referred to as a crazy plan and wacky idea, which both have negative prosody. This indicates a sarcastic perspective on the project. Sarcasm is carried forward when Yemen is described as a desert. Another cynical outlook is the description of Harriet as mastermind (in reference to her intelligence), glamorous, dreamy blond, the slang get her kit off and pose for us (in reference to her beautiful body). The newspaper is highly appreciative of 'British' intelligence and beauty, but would like to keep them in the service of the British, not Sheikh Muhammed.

\subsection{Second Set of Articles}

\subsubsection{Article Number 6}

In this article, categorical assertions are used and quotation marks provided. Like the third article in the first set 
above, this article belongs to category B in narratorial mode neutral.

It is presented as the most powerful and assertive of all the articles for three reasons. First, the characters' attitudes to, and evaluation of, the events or other characters are conveyed in their own words using direct quotation marks. Second, there are only a few evaluative structures, which denotes an objective and external outlook towards what is happening. Third, providing the original words of David Sugden and the spokesman of the prime minister, Jay Vent, enhances the 'authentic' profile of the newspaper.

\subsubsection{Article Number 7}

This is the most complex of all the articles; it contains 14 sentences, 389 words, and complex nominal and verb structures. It contains modal auxiliary verbs (may have been), modal lexical verbs of cognition (understand), modal lexical verbs and adverbs of perception (speculate, note, notably), the adjectival construction (it is unclear what), the epistemic modal adverbs (possibly and indeed), the epistemic noun doubt and the negative adverb no doubt (repeated twice). There is also the if conditional sentence if he is not in Glen Tulloch..., which is epistemically weakened by the epistemic verb speculate and the adverb possibly.

The pronoun we is a marker of category A narration. The Ronnoch and Tulloch is presented as a participant character whose opinions, thoughts and feelings are conveyed straight to the reader. The negative shading employed in the article demonstrates a sense of reluctance to express ideological outlook.

The epistemic and perception modalities, the complicated structures and long sentences, along with the transition in point of view in the end constructs the newspaper as the most inconsistent, and least assured of all the newspapers in the novel. Its critical attitude of the prime minister's claims ends up weakened and losing credibility. Torday is strongly critical of the newspaper.

\subsubsection{Article Number 8}

Here, evaluative structures are used (real world), and the adjectival it is therefore with some pleasure that. There is also the deontic modal verb of necessity need premodified by an evaluative adverb desperately.

This is a category A article that reports from within the story. The newspaper is a participant character. The article is positively shaded, which is manipulative of the ideological outlook of the readers.

Deontic expressions and the evaluative structures positively shade the article. The sarcastic attitude of the Trout and Salmon towards the project and the British government which was initiated in the fourth article is continued here. This editorial describes the watercourses of the Middle East as non-existent. This is a negative construction of the Middle East, and Yemen by implication. It is generalized from the salmon project in Yemen onto the East vs. West. Compared to the negative prosody attached to the East, the West is constructed as the real world.

\subsubsection{Article Number 9}

The ninth article is written in categorical assertions with a few evaluative adjectives and adverbs. Externality and neutrality are foregrounded, and both classify it as belonging to category B in narratorial mode neutral. The article is narrated from a position that is outside the consciousness of any of the characters. There is no evaluation of the feelings and thoughts of the characters. It only reports the events from the point of view of the Yemeni paper the Yemen Daily News.

This article is supportive of the project and of the cooperation of the Yemeni and British governments. This ideological position is carried by the categorical assertions and the evaluative structures (piscatorial, interesting, and gladly). The headline contains the metaphor Fish project spawning new initiative, which carries forward the newspaper's endorsement of the project

\section{Conclusion}

Analysis of the selected extracts from the novel; the nine newspaper articles, reveals interesting findings. There is an extensive use of deontic and boulomaic modalities, with some articles neutrally shaded and a few others negatively shaded. Classification of these modal systems along the lines of Simpson's (1993) reveals that both internal and external modes of narration are used. The modalized, and the modally unmarked, structures function as carriers of ideological outlook in the following ways.

First, modality is used to direct and control the readers' evaluation of the characters and actions that take place in the novel. This control is indicated in the use of category A positive mode of narration in Articles 1, 4, 5, 8. Deontic and boulomaic modalities in the first article, for example, underlines the article's assertiveness and confidence in the truth of its propositions, and steers the Yemeni public's evaluation of the salmon project. Similarly, category A positive in Article 4 influences the reader's ideological outlook. This article advocates a 
negative representation of the East. This is evident, first, in the us vs. them dichotomy, and second, in the association of negative prosody with the East, Yemen, and Sheikh Muhammed. The West, in comparison, is constructed positively; they are 'superior' even at relaxation activities like 'fly fishing'. The 'supremacy' of the British is carried forward in Article 5 with the negative representation of Ms Harriet in the Sun for her attachment to this 'Middle East' project. This outlook is continued in Article 8, where Torday represents the British newspapers as sarcastic of their government's supportive policies.

Second, modality is used as a carrier of ideological evaluation. Articles 3, 6, and 9 are written in category B narratorial mode neutral. The two British newspapers the Times and the Daily Telegraph, and the Yemeni paper the Yemen Daily News are represented as the most authentic. These articles do not attempt to impose an ideological perspective on the reader; they report events and leave judgment to the reader.

Third, modality is employed as a tool of ideological positioning and alienation. Article 2 is written in category B narratorial mode negative and Article 7 in category A negative. The negative shading in both articles, evident in the use of epistemic and perception modalities, constructs them as unassertive towards the truth of the information they provide, resulting in a weak and inconsistent ideological outlook. The sense of alienation created by the negative shading is intensified by the external point of view used to narrate Article 2, and in the long and complex structures employed in Article 7. This results in distancing the readers from the propositional content of the articles and alienating them from the course of action in the narrative.

\section{References}

Alaghbary, G. S. (2014). The United States' reaction to the Arab Spring: A critical stylistic analysis. Journal of Language Aggression and Conflict, 2(1), 151-175. https://doi.org/10.1075/jlac.2.1.06ala

Al-Nakeeb, O. (2014). Ideology and point of view in Salmon Fishing in the Yemen: A critical linguistic analysis (Unpublished master's thesis). Taiz University, Yemen.

Al-Olaqi, F. (2012). English literary portrait of the Arabs. Theory and Practice in Language Studies, 9(2), 1767-1775. https://doi.org/10.4304/tpls.2.9.1767-1775

Bonyadi, A. (2011). Linguistic manifestations of modality in newspaper. International Journal of Linguistics, 3(1). http://dx.doi.org/10.5296/ijl.v3i1.799

Carter, R., Goddard, A., Reah, D., Sanger, K., \& Bowring, M. (1997). Working with texts: A core introduction to language analysis. London: Routledge. https://doi.org/10.4324/9780203468470

Collin, R. (2012). Salmon Fishing in the Yemen, review. the Telegraph. Retrieved from http://www.telegraph.co.uk/culture/film/filmreviews/9215129/Salmon-Fishing-In-The-Yemen-review.html

Eagleton, T. (1991). Ideology: An introduction. London: Verso.

Fairclough, N. (1989). Language and power. London: Longman.

Fowler, R. (1977). Lingusitics and the novel. London: Methuen \& Co. Ltd.

Fowler, R. (1991). Language in the news: Discourse and ideology in the press. London: Routledge.

Fowler, R., \& Kress, G. (1979). Critical linguistics. In R. Fowler, B. Hodge, G. Kress, \& T. Trew (Eds.), Language and control (pp. 185-221). London: Routledge \&. Kegan Paul.

Hall, S. (1982). The rediscovery of ideology: the return of the repressed in media studies. In M. Gurevitch, M. Curran, \& J. Woollacott (Eds.), Culture, society and the media. London: Methuen.

Jordon, M. (2007). Spin salmon the right way and it's a tasty diplomatic dish. the Age. Retrieved from http://www.theage.com.au/news/book-reviews/salmon-fishing-in-the-yemen/2007/02/16/1171405426294.ht $\mathrm{ml}$

Kačmárová, A. (2011). Modality—A framework for conveying judgments. SKASE Journal of Theoretical Linguistics, 8(1). Retrieved from http://www.skase.sk/Volumes/JTL18/pdf_doc/02.pdf

Lea, R. (2007). A real pig's cheer. the Guardian. Retrieved from http://www.guardian.co.uk/books/2007/may/03/news.bollingerprize

León, E. (2001). An exploration of modality in H. Pinter's The Dumb Waiter. Centro Virtual Cervantes, (24), 259-268. Retrieved from http://cvc.cervantes.es/literatura/cauce/pdf/cauce24/cauce24_16.pdf

Lyons, J. (1977). Semantics (Vol. 2). Cambridge: Cambridge University Press. 
Mackintosh-Smith, T. (2007). Faith, hope, love... and fish. the Guardian. Retrieved from $\mathrm{http} / / / \mathrm{www}$.theguardian.com/books/2007/feb/24/featuresreviews.guardianreview19.html

Marx, K., \& Engels, F. (1970). The German ideology (Vol. 1). International Publishers Co.

McIntyre, D. (2006). Point of view in plays. Amsterdam: John Benjamins Publishing Co. https://doi.org/10.1075/lal.3

Palmer, F. (2003). Modality in English: Theoretical, descriptive and typological issues. In R. Facchinetti, M. Krug, \& F. Palmer, Modality in contemporary English (pp. 1-17). Berlin: Mouton de Gruyter. https://doi.org/10.1515/9783110895339.1

Parina, J. C., \& D Leon, K. D. (2014). A stylistic analysis of the use of modality to identify the point of view in a short story. The Southeast Asian Journal of English Language Studies, 20(2), 91-101. http://dx.doi.org/10.17576/3L-2014-2002-08

Sadati, S. (2013). The influence of ideological state apparatuses in identity formation: Althusserian reading of Amiri Baraka's "In Memory of Radio". International Journal of English and Literature, 4(10), 480-485. Retrieved from http://www.academicjournals.org/IJEL

Seng, W. (2013). Fishing for Geopolitics: "Salmon Fishing in the Yemen". [Review of the movie Salmon Fishing in the Yemen, produced by Lionsgates and BBC Films, 2011]. GE2222: Politics \& Space, National University of Singabore. Retrieved from https://www.academia.edu/4978135/Popular_Geopolitics_Movie_Review_Salmon_Fishing_in_the_Yemen

Simpson, P. (1993). Language, ideology and point of view. London: Routledge. https://doi.org/10.4324/9780203312612

Simpson, P. (2004). Stylistics: A resource book for students. London: Routledge.

Torday, P. (2007). Salmon fishing in the Yemen. London: Phoenix.

van Dijk, T. A. (1998). Ideology: A multidisciplinary approach. London: Sage.

Wales, K. (2001). A dictionary of stylistics (2nd ed.). London: Pearson Education Limited.

\section{Appendix A}

\section{Article number 1 extracted from file 7 in Torday $(2007$, p. 87)}

Article in the Yemen Observer, 14 August

Fishing project for western highlands

Sheikh Muhammad ibn Zaidi has surprised the Arab world with his decision to introduce salmon fishing into the Wadi Aleyn in the Heraz. Yemenis may understandably ask many questions about the legitimacy of this project. We say that we should wait and see what the scientific reality of the salmon project turns out to be.

The project is being debated in a lively manner at family dinners and at khat chews. There are many who think that the introduction of salmon into a desert country is neither a realistic nor an economic proposition. Others however state that the project is being supported by a leading fisheries scientist from the UK and that there is a real prospect in future years of our tourist industry being boosted by the sale of salmon fishing permits.

The agriculture and health ministry declined to comment but we understand that the present Aquatic Law No.42 does not expressly forbid the development of a salmon fishery in the Yemen. Therefore Sheikh Muhammad is entitled to develop such a fishery without the need to seek further consent from the government.

\section{Article number 2 extracted from file 7 in Torday (2007, pp. 88-89)}

Article in the International Herald Tribune, 16 August

Yemeni sheikh plans new ecosystem for wadis

Sana'a, Yemen Republic

Sheikh Muhammad ibn Zaidi, a key figure in Yemeni political circles, has long been noted for his pro-Western views in a country whose relationship with Western states has sometimes been troubled. On Sunday he urged President Saleh to lend his backing to a revolutionary eco-project that has received some support in UK government circles.

Sheikh Muhammad is planning to spend millions of pounds sterling with the British government to introduce wild 
Scottish salmon into a wadi in the western Yemen. In stark contrast to US policy, which currently involves further military build-ups in Saudi Arabia and Iraq, the UK now appears to be shifting its political ground. Although British government officials deny any formal relationship with Sheikh Muhammad, nevertheless a UK government agency, the National Centre for Fisheries Excellence, has taken a leading role in this environmentally challenging project. British policy in the region now appears to be looking for ways to take cultural and sporting images, likely in an effort to soften the impact of recent military actions in southern Iraq.

The funding will be provided by Sheikh Muhammad. UK government officials today distanced themselves from the project, claiming it was a private-sector initiative. However, it is likely that such a major scheme involving some of the world's most prestigious fisheries scientists could not proceed without sanction from Prime Minister Jay Vent's office.

Some observers speculate that Sheikh Muhammad's initiative may not be universally welcome in his own province. The area is home to several radical Wahhabi madrasas, religious training schools, and it is understood that salmon fishing is regarded as an unacceptable activity by some Wahhabi imams. Water is also a scarce resource in the Yemen, and its diversion into the wadis to support a run of salmon will not be universally popular in a country where the availability of water is often a matter of life and death.

\section{Article number 3 extracted from file 7 in Torday (2007, pp. 89-90)}

Article in the Times, 17 August

\section{British fisheries scientists in major row}

Concerns were raised yesterday in Parliament that a key Government agency, the National Centre for Fisheries Excellence (NCFE), is going outside its mandate. Set up a decade ago to support the work of the Environment Agency in monitoring and improving the health of rivers in England and Wales, NCFE is now said to have diverted over 90 per cent of its resources into a project to introduce Atlantic salmon into the Yemen.

The Department for Environment, Food and Rural Affairs (DEFRA) confirmed that the funding for the Yemen salmon project is not coming from the UK taxpayer but has been met entirely from private-sector sources. However, questions are being asked as to whether this is an appropriate use of a key government department at a time when so many environmental and other challenges face rivers in England and Wales as a result of global warming and the risks from agricultural and industrial pollution to our rivers. A spokesman for the RSPB confirmed that, if the Yemen salmon project went ahead, the society would seek to have English cormorants exported to the Yemen, to ensure that the natural checks and balances on any salmon river were maintained.

\section{Article number 4 extracted from file 7 in Torday (2007, pp. 90-1)}

Extract from Trout \& Salmon, 18 August

\section{Comment}

We acknowledge that we have, from time to time, sung the praises of the National Centre for Fisheries Excellence. This organisation had established for itself within the angling community a reputation for good science and common sense.

Fly-fishing has become "cool" in the USA, and even in the UK we are discarding our waxed jackets for the latest in clothing technology from Orvis, Snowbee and many other manufacturers. Films are made about fishing, once regarded as the most boring of sports. This trend was firmly set by the making of A River Runs Through It in 1992, while television programmes about fishing such as A Passion for Angling and Go Fishing attract prime-time audiences and are repeated endlessly on satellite channels.

So, fishing is fashionable, and its appeal crosses borders and it is becoming truly international, but nothing so far has prepared us for the idea that the mountains of the Heraz, in the Republic of Yemen, are soon to become the next playground for internationally minded game fishermen seeking the latest salmon fishing thrill.

Who is making this happen? A prominent and wealthy citizen of the Yemen has teamed up with the National Centre for Fisheries Excellence, an organisation we would not have anticipated would become involved in an adventure of this kind. But money talks and the millions of pounds that Sheikh Muhammad of the Wadi Aleyn is spending are talking loudly enough to grab the attention of the NCFE and even (it is rumoured) the director of communications at Number 10 Downing Street.

We have looked back through our files to find a similar instance of such absurdity from a government department, but we are unable to find anything to parallel this. At a time when the health of English and Welsh rivers is so fragile, and stocks of salmon and sea trout, not to mention brown trout, appear threatened by climatic change, our 
best fisheries scientists have been committed to a hare-brained scheme which is of absolutely no benefit whatsoever to our own angling community here in the UK.

\section{Article number 5 extracted from file 7 in Torday (2007, pp. 91-92)}

Extract from the Sun, 23 August

"Chest" wader

Glamorous Harriet Chetwode-Talbot, the dreamy blonde who is masterminding the crazy plan to bring salmon fishing to the Yemen, refused to talk to our reporter when we rang her today. We contacted her at exclusive West End estate agents Fitzharris \& Price, to ask her to comment on her wacky idea-let's all go salmon fishing in the desert! She couldn't tell us too much about how it would all work, and refused to say anything about her Yemeni boss, Sheikh Muhammad. So we asked if she would like to get her kit off for our photographer and pose for us in "chest" waders. We're still waiting for her answer!

\section{Appendix B}

\section{Article number 6 extracted from file 18 in Torday (2007, pp. 184-185)}

Article in the Daily Telegraph, 1 November

Prime minister has other fish to fry

Following the reported assassination attempt on a Yemen sheikh in the Scottish Highlands, in a statement today a spokesman for the prime minister distanced his office from the Yemen salmon project. The spokesman denied there had been any such incident and cited the absence of any involvement by local police forces.

The Yemen salmon project was officially launched in June this year. It initially received technical support from the National Centre for Fisheries Excellence. Now NCFE has announced it has ceased advising the salmon project team. David Sugden, director of NCFE, stated: "It is not a priority for the centre. We did carry out some advisory work in the early stages of the project, but the centre's mandate has always been, and will continue to be, scientific work to support the Environment Agency and others in their task of looking after fisheries in English and Welsh rivers. Getting salmon to run up watercourses in the Yemen has never been high on our agenda, and although we were delighted to make an initial technical contribution, the project falls well outside the mainstream of our work."

In July this year Prime Minister Jay Vent indicated his support for the Yemen salmon project, although the project never achieved official inter-governmental status. Sensitivities about other British and US initiatives in the region have resulted in the prime minister's office backing away from a closer association with salmon fishing in the Yemen.

The spokesman from Number 10 Downing Street added, "The prime minister is always supportive of sporting and cultural initiatives such as this one, but at the moment he has other fish to fry."

Article number 7 extracted from file 18 in Torday (2007, pp. 186-187)

Editorial, the Rannoch \& Tulloch Reporter, 3 November

Prime minister casts doubt upon the veracity of our reporter

Last week we published a detailed account of an alleged attempt on the life of an eminent local resident, the Laird of Glen Tulloch, Sheikh Muhammad.

Eyewitness reports which reached us suggested that the individual concerned in this attempt was wearing a Campbell tartan which we feel sure he was not entitled to wear but no doubt was intended to help him avoid detection until he was close enough to make the attempt. We understand that this individual may have been of Arab extraction and that his attempt to pass himself off as a native of this glen was not notably successful. We are given to understand that the alleged would-be murderer was only restrained at the last moment by the intervention of one of the sheikh's employees, the respected and enterprising Colin McPherson.

We understand Mr McPherson detained him with a size 8 Ally Shrimp treble hook on a 15-pound line, and took less than five minutes to play him. After that achievement, it is unclear what the subsequent fate of the individual was. We make no allegations, but merely speculate that if he is not in Glen Tulloch, then he is somewhere else, possibly somewhere with more sand than Glen Tulloch.

No doubt events in remote Scottish glens are of little interest to the London or even the Edinburgh press these days, but we were surprised that no other paper saw fit to reproduce our scoop. Indeed the first notice that anyone outside of our regular readers took of this event was when an official from the prime minister's office rang up and asked us what our source for the story was. It is not this newspaper's policy, and never has been, to identify a journalistic 
source without consent. In this case we have no such consent. We also note from the national press the day after we broke the story, that it was labelled a "hoax", by a spokesman from the prime minister's office. We are not given to hoaxes in this paper. We are here to report the facts, and we are appalled and alarmed by the casual slur by the prime minister's spokesman on the integrity and competence of the Rannoch and Tulloch Reporter, which has been faithfully reporting on events up and down the length of Glen Tulloch for the last hundred years.

Article number 8 extracted from file 18 in Torday (2007, pp. 187-188)

\section{Editorial, Trout \& Salmon}

\section{Traditional British common sense}

We are pleased, even delighted, to record a rare victory for common sense in the world of British fisheries science. Readers will recall our dismay earlier this year at the way the National Centre for Fisheries Excellence had been drawn into supporting the Yemen salmon project. We commented that there were enough unsolved problems in our own rivers without diverting scarce resources to what sounded like a scientifically impossible project to introduce salmon into non-existent watercourses in the Middle East.

It is therefore with some pleasure that we saw David Sugden (the director of NCFE) quoted in the national press as saying that NCFE was no longer involved in this project. We might all speculate as to the reasons behind this apparent change of heart by the government, whose interest, we suspect, led to the involvement of NCFE in the first place.

Now NCFE has freed up the considerable resources it was devoting to the Yemen salmon project, could we, through these pages, urge Director David Sugden to allocate time to some scientific issues in the real world? We desperately need more research into the effects of rapid changes in water temperature on the hatching of dace eggs.

Article number 9 extracted from file 18 in Torday (2007, pp. 188-189)

Article in the Yemen Daily News

\section{Translated from the Arabic by tarjim.ajeeb.com}

(Arabic Internet-based translation site).

\section{Fish project is spawning new initiatives}

The piscatorial initiative of Sheikh Muhammad ibn Zaidi bani Tihama is reaching new levels today. Work has now started on the construction of artificial lakes in which salmon from UK will swim around until summer rains are coming. When the rains are coming, the salmon will leave the lakes and swim up the Wadi Aleyn.

Considerable sporting interest is already arousing amongst the peoples in the Wilayat Aleyn. Well known and famous local businessman, Ali Husseyn, is already importing through his extremely notorious and excellent business Global Import Export LLP, the finest fishing rods manufactured by his family interests in Mumbai, India.

Also interesting tourism possibilities are occurring, with the promised opening after Ramadan of two new guest bedrooms in the Aleyn Rest House, with inside washing room facilities in the European style.

Soon a team of top scientists and engineers is coming with the sheikh to stay at his palace and make scientific observations and deductions, in order to have the best possibility for the future survival and sporting value of the introduced fish.

The Yemen Daily News is gladly announcing such initiative by Sheikh Muhammad, who is also a personal friend of the British Prime Minister Mr Vent.

\section{Copyrights}

Copyright for this article is retained by the authors, with first publication rights granted to the journal.

This is an open-access article distributed under the terms and conditions of the Creative Commons Attribution license (http://creativecommons.org/licenses/by/4.0/). 